\title{
Evaluation of direct shear strength of self-consolidating and conventional concretes
}

\author{
Avaliação da resistência ao cisalhamento \\ direto de concretos autoadensável e convencional
}

\author{
Kellyn Maressa Pufal ${ }^{1}$, Gustavo Savaris ${ }^{2}$, \\ Carlos Eduardo Tino Balestra ${ }^{2}$, Gustavo Henrique Dalposso ${ }^{2}$, \\ Sergio Luis González Garcia ${ }^{3}$,
}

\footnotetext{
${ }^{1}$ Universidade Federal do Rio Grande do Sul, Programa de Pós-Graduação em Engenharia Civil, Av. Osvaldo Aranha, n99, 90035-190, Porto Alegre, RS, Brasil

${ }^{2}$ Universidade Tecnológica Federal do Paraná, Coordenação de Engenharia Civil, Rua Cristo Rei, n $19,85902-490$, Toledo, PR, Brasil

${ }^{3}$ Universidade Estadual do Norte Fluminense Darcy Ribeiro, Laboratório de Engenharia Civil, Av. Alberto Lamego, n²000, 28013-602, Campos dos Goytacazes, RJ, Brasil

e-mail: kellynmaressa@hotmail.com, gsavaris@utfpr.edu.br; carlosbalestra@utfpr.edu.br; gustavodalposso@utfpr.edu.br, liluiser@uenf.br
}

\section{RESUMO}

O concreto autoadensável apresenta propriedades que aperfeiçoam o processo construtivo e a sua principal característica é a capacidade de escoamento por ação de seu peso próprio e preenchimento das formas sem a necessidade de adensamento mecânico. Entretanto, incerteza sobre sua resistência ao cisalhamento, devido à diferenças no volume e dimensões do agregado graúdo em relação ao concreto vibrado convencional, é uma das principais barreiras em sua aceitação. Dosagens de concreto autoadensável requerem geralmente a redução do volume de agregado graúdo e a adição de materiais finos, para aumento da fluidez, e a utilização de agregados graúdos com menor granulometria, o que influencia diretamente no mecanismo de engrenamento dos agregados. Neste trabalho, duas misturas de concreto, convencional e autoadensável, foram utilizadas para moldagem de corpos de prova, submetidos ao ensaio de cisalhamento direto, visando avaliar a resistência ao cisalhamento direto destes concretos. Os resultados demonstraram uma redução da resistência ao cisalhamento no concreto autoadensável, atribuída à utilização de agregado graúdo de menor granulometria e em menor volume, combinada com o aumento de teor de finos na mistura. Os resultados experimentais foram comparados com equações propostas na literatura, verificando-se que para o concreto autoadensável estas equações subestimam as resistências últimas ao cisalhamento. Assim, este trabalho contribui para a formação de um banco de dados visando estabelecer equações para estimar a resistência do concreto autoadensável.

Palavras-chave: Concreto autoadensável. Cisalhamento direto. Resistência. Tensões cisalhantes. Engrenamento.

\section{ABSTRACT}

The self-consolidating concrete presents properties that improve the constructive process, it has the main characteristic of flowing under its own weight and completely filling the formwork, without the need of compaction. However, the uncertainty about its shear strength, due to the differences in coarse aggregate volume and size of this concrete compared to conventional vibrated concrete, is one of the main barriers to its acceptance. Self-consolidating concrete mixtures requires generally the reduction of coarse aggregate content and addition of fines materials to obtain flowability and the reduction of particles size directly influences the mechanism of aggregate interlock. In this work, two concrete mixtures, conventional and self-consolidating, were used for casting test specimens, submitted to the direct shear test, in order to evaluate the direct shear strength of these concretes. The results showed a reduction of the shear strength for the self-compacting concrete, attributed to the use of coarse aggregate with smaller particle size, the reduced volume of coarse aggregate and the larger fines content in the mixture. The experimental results were compared with equations pro- 
posed in the literature, demonstrating that for self-consolidating concrete these equations underestimate the ultimate shear strengths. Thus, this work contributes to the formation of a database aiming the establishment of equations to estimate self-consolidating concrete shear strength.

Keywords: Self-consolidating concrete. Direct shear. Strength. Shear Stress. Interlock.

\section{INTRODUCTION}

Concretes with special characteristics, such as high strength, durability and flowability, have been developed in the last decades in order to improve the quality of the structures. Among these innovations, selfconsolidating concrete (SCC) was developed with the characteristic of spreading under its own weight and filling the formworks without the use of vibrators, without segregating even after passing through obstacles [1].

The production of self-compacting concrete uses the same materials of the conventional concrete (CC): cement, aggregates and water, but requiring mineral additives, superplasticizers and viscosity modifiers to increase fluidity and viscosity. According to LOONEY et al. [2], it is possible to obtain a SCC by three methods. In the first one, the percentage of coarse aggregates is reduced, increasing the percentage of fines in the mix (usually mineral additions). The second method maintains the proportions of coarse aggregates and paste, and the fluidity and stability of the mixture are modified with water-reducing additives and/or viscosity modifiers (superplasticizers). The third method makes a mixture between the first two, thus replacing the volume of coarse aggregates by fines and also using additives to change the fluidity and reduce the water consumption of the concrete, in order to obtain a SCC with reduced cost.

A significant number of studies about SCC deal with materials, proportions of the mixtures and their properties in the fresh and hardened state [3-7], with little information about structural properties, such as shear strength, becoming an obstacle to the acceptance of self-consolidating concrete as a high quality structural material [8-12]. The main uncertainty regarding the structural behavior of SCC lies in its shear strength.

According to RANDL [13], the shear strength in reinforced concrete is formed by three mechanisms: the aggregate interlock and the adhesive bonding of the particles of the materials, the friction developed between the interfaces of the cracks and the dowel action of the reinforcement that crosses these cracks. In concrete elements without transverse reinforcement only the first mechanism occurs.

SHERWOOD et al. [14] demonstrated that the size of the aggregate used in the concrete influences the shear strength, acting directly on the mechanism of aggregate interlock. Thus, the reduction of aggregate size to obtain SCC would result in lower shear strength. Tests performed with CC and SCC beams without transverse reinforcement concluded that the SCC presents lower ultimate shear strength, attributed to the reduction of aggregate size and content in relation to $\mathrm{CC}$ [9-11].

DESNERCK et al. [12] evaluated the effect of the lower aggregate content in SCC compared to the $\mathrm{CC}$ on the aggregate interlock by push-off tests. The ultimate shear strength of SCC presented values around $15 \%$ and $20 \%$ higher than conventional concrete, attributed to a probable improvement in the structure of the matrix of this material, being emphasized by the authors the importance of new studies to evaluate the influence of aggregate size in concrete.

KIM et al. [15] performed push-off tests to investigate the influence of SCC aggregate and paste volumes on the shear capacity and these results were compared with those obtained from similar CC samples, concluding that not only the coarse aggregate volume but also the aggregate type has significant effects on the aggregate interlock.

MATTOCK [16] proposed Equation 1 to estimate the ultimate shear strength of conventional concrete specimens as the sum of the concrete strength before cracking and the effects of transverse reinforcement:

$$
\tau_{u}=0.467 f_{c}^{0.545}+0.8\left(\rho_{s w} f_{y}+\sigma_{n}\right) \ngtr 0.3 f_{c}
$$

where $f_{c}$ is the compressive strength of concrete, $\rho_{s w}$ is the transverse reinforcement ratio, $f_{y}$ is the reinforcement yield strength, and $\sigma_{\mathrm{n}}$ is the normal stress acting on the shear plane.

Using the Mohr-Coulomb theory to evaluate the ultimate capacity of concrete specimens, SONNENBERG et al. [17] proposed Equation 2 to estimate the shear strength of uncracked concrete with normal stress acting on the shear plane of lower than $0.15 \mathrm{f}_{\mathrm{c}}$.

$$
\tau_{\mathrm{u}}=1.41 \sigma_{n}+0.1 f_{c}
$$

XU et al. [18] investigated shear transfer behavior in initially uncracked reinforced concrete members 
using finite element modeling method, validated with experimental push-off tests carried out at laboratory. Considering the failure of the concrete obtained by using the Mohr's circles, empirical equations for describing the non-linear relationship of equivalent lateral normal and shear stress were constructed. A multiple regression analysis resulted in Equation 3 for ultimate shear stress:

$$
\tau_{\mathrm{u}}=\left(-0.038 f_{c}^{0.21}\right)\left(\sigma_{n}+\rho_{s w} f_{y}\right)^{2}+0,33 f_{c}^{0.5}\left(\sigma_{n}+\rho_{s w} f_{y}\right)+0,3 f_{c}^{0.75}
$$

Most studies presented in literature and code design equations are based on experimental results using conventional concrete. Considering the uncertainties about the shear strength of conventional selfcompacting concrete, due to the particularities of the mixture, this work aims to evaluate the direct shear strength of two concrete mixtures, conventional and self-compacting, with differences in coarse aggregate volume and size, and to compare the results with the equations proposed in literature, thus contributing to the development of the use of self-compacting concrete in structures.

\section{EXPERIMENTAL PROGRAMME}

\subsection{Materials and concrete mixtures}

Two concrete mixtures, one conventional and other self-compacting, were used to evaluate the effect of the reduction of coarse aggregate size and content on the shear strength. Details of concretes mix proportions are presented in Table 1. Type CP V-ARI Brazilian cement, similar to ASTM Type III, and natural quartz sand of river, with fineness modulus equal to 2.16 and a density of $1.58 \mathrm{~kg} / \mathrm{dm}^{3}$, were used in both concretes. In the conventional concrete, crushed basalt with a maximum nominal size of $19 \mathrm{~mm}$ and density of 2.84 $\mathrm{kg} / \mathrm{dm}^{3}$ was used as coarse aggregate, while for the self-compacting concrete the same aggregate had a maximum nominal size of $9.5 \mathrm{~mm}$ and density of $2.78 \mathrm{~kg} / \mathrm{dm}^{3}$. The SCC mixture was obtained from CC by reducing the coarse aggregate content, replaced by equivalent volume of sand, partial replacement of $25 \%$ of sand content by limestone filler and adding a polycarboxylate based superplasticizer to increase the flowability and viscosity of the mixture. The water-cement (w/c) ratio was kept constant at 0.52 for both mixes.

Table 1: Mixture proportions for CC and SCC mixtures $\left(\mathrm{kg} / \mathrm{m}^{3}\right)$.

\begin{tabular}{c|c|c|c|c|c|c|c}
\hline \multirow{2}{*}{ MIXTURE } & \multirow{2}{*}{ CEMENT } & \multirow{2}{*}{$\begin{array}{c}\text { LIMESTONE } \\
\text { FILLER }\end{array}$} & \multirow{2}{*}{ SAND } & \multicolumn{2}{c|}{ COARSE AGGREGTE } & \multirow{2}{*}{ WATER } & \multirow{2}{*}{ SUPERPLASTICIZER } \\
\cline { 5 - 6 } & & & $\mathbf{1 9} \mathbf{~} \mathbf{m}$ & $\mathbf{9 . 5} \mathbf{~ m m}$ & & \\
\hline CC & 384.75 & - & 817.85 & 1031.83 & - & 200.07 & - \\
\hline SCC & 384.75 & 286.25 & 814.19 & - & 722.28 & 200.07 & 1.92 \\
\hline
\end{tabular}

\subsection{Casting of specimens}

The concretes were mixed in a $240 \mathrm{~L}$ capacity batch mixer. For each mixture, 85 liters were produced, sufficient for casting 6 cylindrical specimens $(100 \times 200 \mathrm{~mm})$, used for the determination of compressive and splitting tensile strength, and 6 prismatic specimens $(150 \times 150 \times 500 \mathrm{~mm})$ for the direct shear tests.

SCC specimens were cast without consolidation, filling the formwork, and CC were consolidated using electrical vibrators. Steel plates, $19 \mathrm{~mm}$ wide and $3 \mathrm{~mm}$ tick, were used to reduce the shear plane in sections $150 \mathrm{~mm}$ apart (Figure 1), in order to induce the rupture of the specimen in these two shear planes. 


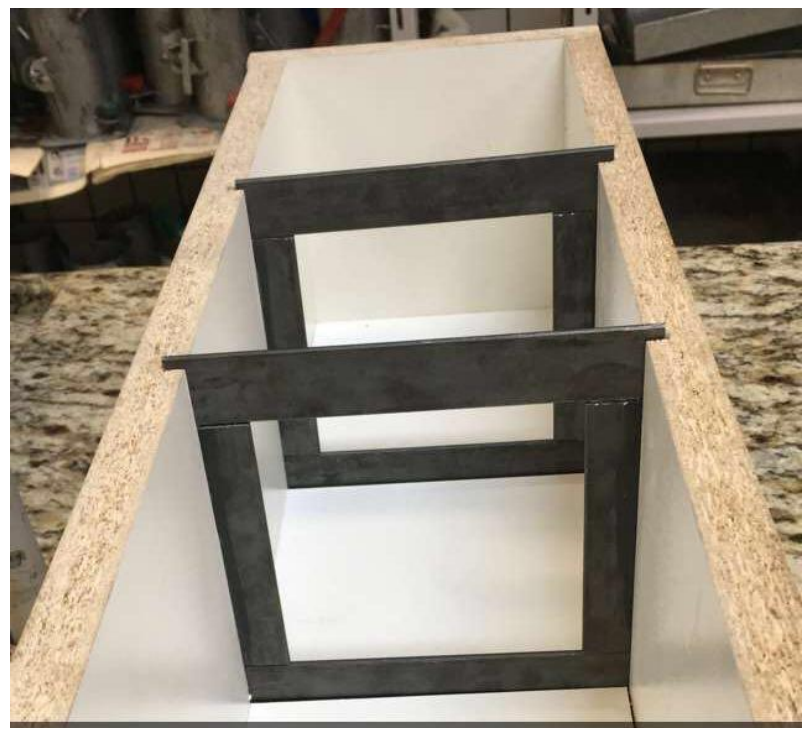

Figure 1: Prismatic specimens formworks.

Formworks were removed after 24 hours of casting and the specimens were cured submerged in water for seven days and then air cured in the laboratory until they were 28 days old, under conditions of average temperature and relative humidity mean of $22{ }^{\circ} \mathrm{C}$ and $72 \%$, respectively.

\subsection{Direct shear test}

Shear tests were conducted according to SF-6 standard test method [19], in a universal test machine with load capacity of $1000 \mathrm{kN}$, using a steel apparatus as shown in Figure 2. Load was applied continuously and without impact, at displacement rate of $2 \mathrm{~mm} / \mathrm{min}$, producing shear stresses simultaneously in the two previously defined planes.

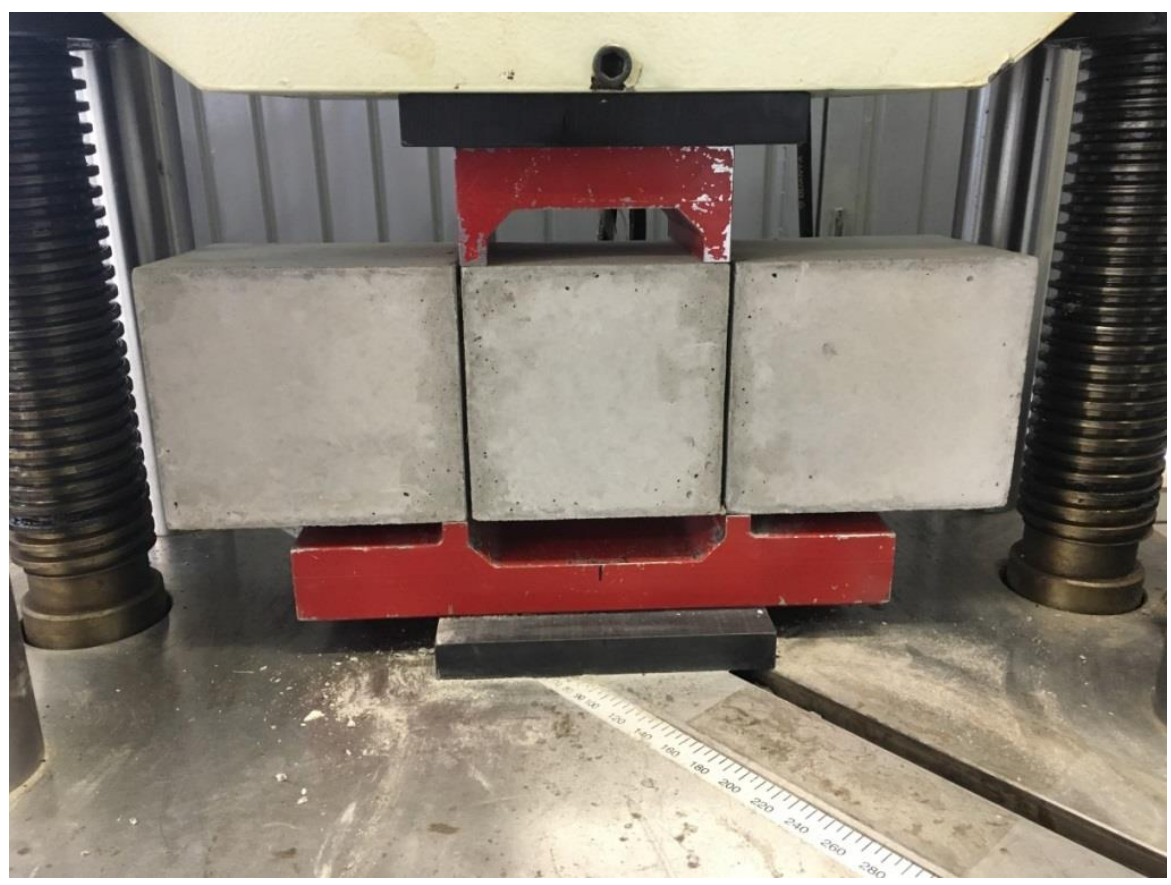

Figure 2: Concrete specimen and steel apparatus for direct shear test.

The ultimate shear strength was calculated according with the Equation 4.

$$
\tau_{\mathrm{u}}=\frac{F}{2 . A c}
$$


where $\tau_{\mathrm{u}}$ is the ultimate shear stress $(\mathrm{MPa}), \mathrm{F}$ is the mean peak load supported $(\mathrm{N})$ and $\mathrm{A}_{\mathrm{c}}$ is the shear plane area $\left(\mathrm{mm}^{2}\right)$.

\section{RESULTS AND DISCUSSION}

\subsection{Concretes properties}

It was possible to obtain a mixture of SCC from CC with the partial replacement of sand by limestone filler and the reduction of the coarse aggregate content, replaced by equivalent volume of sand.

Table 2 presents the fresh and hardened properties of CC and SCC mixtures. During the production of the concrete, the traditional slump test according to NBR NM 67 [20] was conducted for CC, while the slump flow test V-funnel and L-box tests were conducted according to NBR 15823 [21] to evaluate the flowability, stability and the passing ability of SCC. For both concretes 100x200 mm control cylinders were used to determine compressive strength $\left(\mathrm{f}_{\mathrm{c}}\right)$, according to NBR 5739 [22], and splitting tensile strength $\left(\mathrm{f}_{\mathrm{ct}}\right)$, according to NBR 7222 [23], at 28 days of age.

Table 2: Fresh and hardened properties of CC and SCC.

\begin{tabular}{c|c|c|c|c|c|c}
\hline MIXTURE & SLUMP $(\mathbf{m m})$ & $\begin{array}{c}\text { SLUMP FLOW } \\
(\mathbf{m m})\end{array}$ & $\begin{array}{c}\text { V-FUNNEL } \\
(\mathbf{s})\end{array}$ & $\begin{array}{c}\text { L-BOX INDEX } \\
(\mathbf{\%})\end{array}$ & $\begin{array}{c}\mathbf{f}_{\mathrm{c}, \mathbf{m}} \\
\mathbf{( M P a )}\end{array}$ & $\begin{array}{c}\mathbf{f}_{\mathrm{ct}, \mathbf{m}} \\
\mathbf{( M P a})\end{array}$ \\
\hline $\mathrm{CC}$ & 125 & - & - & - & 46.19 & 3.86 \\
\hline $\mathrm{SCC}$ & - & 760 & 11.68 & 89.3 & 56.28 & 4.18 \\
\hline
\end{tabular}

In the fresh state CC presented slump equal to $12.5 \mathrm{~cm}$, and it can be classified of consistency S100, according to NBR 8953 [24]. SCC mixture satisfied recommended values according to NBR 15823 [21], without segregation or bleeding. The mean diameter in two perpendicular measurements was $760 \mathrm{~mm}$, classified as SF3 and recommended for structures with large amount of steel reinforcement. The flow time at the V-funnel was 11.68 seconds, classified as VF2, and the L-box index was 0.893 , corresponding to class PL2, being suitable for most structural applications. These results demonstrated that the mixtures are suitable for the use in structural elements.

Although the w/c ratio was the same in the two mixtures, it was verified that the SCC presented compressive and tensile strength greater than the CC. This difference can be attributed to a better compaction and the improvement in the transition zone due to the higher content of fine materials in the SCC [25-27].

\subsection{Direct shear strength}

During direct shear tests the load was applied continuously until failure. No cracks were observed outside the shear plane previously defined, occurring a sudden failure of the specimens in most of the cases in the two shear planes simultaneously (Figure 3), but in two specimens of the CC the rupture occurred only at one of the planes, at lower applied force than the other specimens and these results were discarded. 


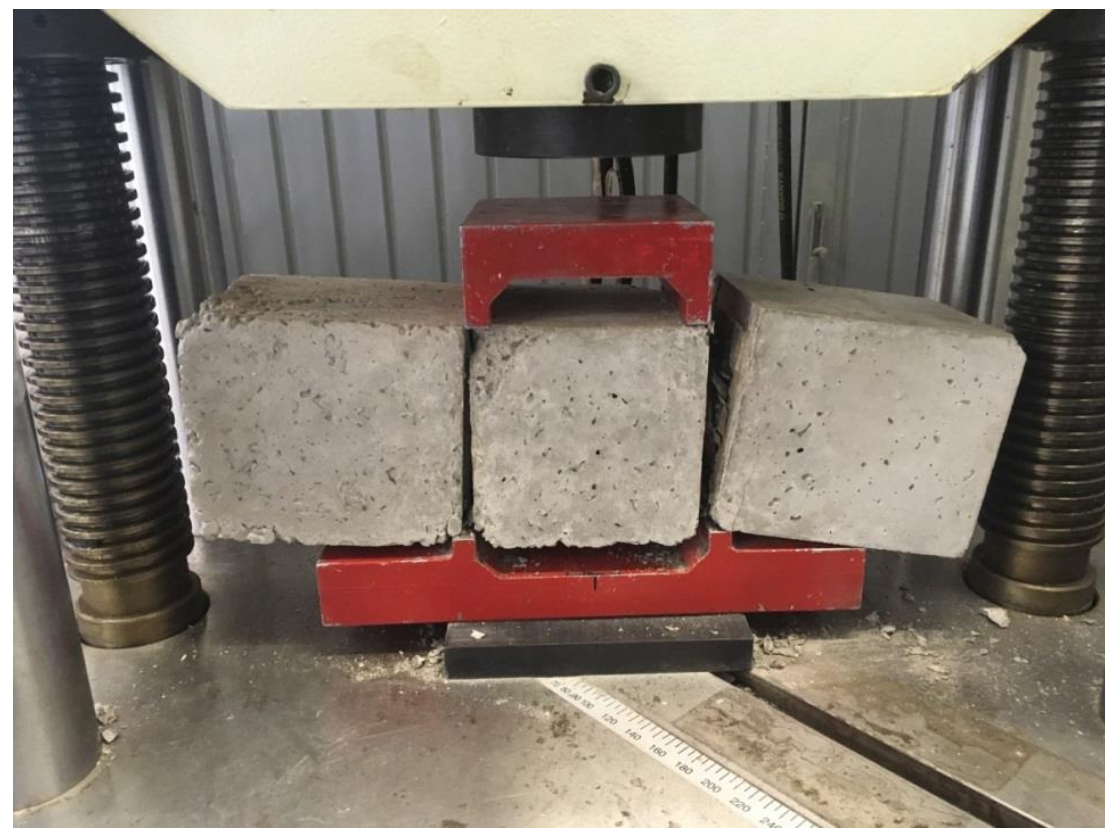

Figure 3: Shear failure of SCC specimen.

After the failure, the shear plane dimensions were verified using a caliper, and the ultimate shear strength was calculated, results are shown in Table 3. The mean shear strength of CC is higher than SCC, however, the values of ultimate shear stress of SCC show less variability.

Table 3: Ultimate shear strength of CC and SCC specimens.

\begin{tabular}{c|c|c}
\hline \multirow{2}{*}{ SPECIMEN } & \multicolumn{2}{|c}{$\mathbf{T}_{\mathbf{u}}(\mathbf{M P a})$} \\
\cline { 2 - 3 } & $\mathbf{C C}$ & SCC \\
\hline 1 & - & 4.59 \\
\hline 2 & - & 4.63 \\
\hline 3 & 7.41 & 3.57 \\
\hline 4 & 8.47 & 4.30 \\
\hline 5 & 4.88 & 4.33 \\
\hline 6 & 7.13 & 3.74 \\
\hline Mean stress (MPa) & 6.97 & 4.19 \\
\hline Standard deviation (MPa) & 1.51 & 0.44 \\
\hline
\end{tabular}

Considering the small number of samples, a non-parametric method is needed to compare them. This is due to the fact that traditional inferential analyzes use asymptotic information, and if the sample is small, the analyzes can be incorrect. Thus, the bootstrap resampling method [28] was used to elaborate a percentile interval of $95 \%$ confidence for the difference between the means. Using the software R [29] one thousand samples were generated with replacement of the CC and SCC data sets, the mean was calculated for each set and finally the differences between the means were calculated. The set formed by the 1000 differences between the means represents the empirical distribution of the differences between the means. By ordering the 1000 values of the differences and eliminating 25 values from each end, we determined the $95 \%$ confidence interval percentile shown in Figure 4. 


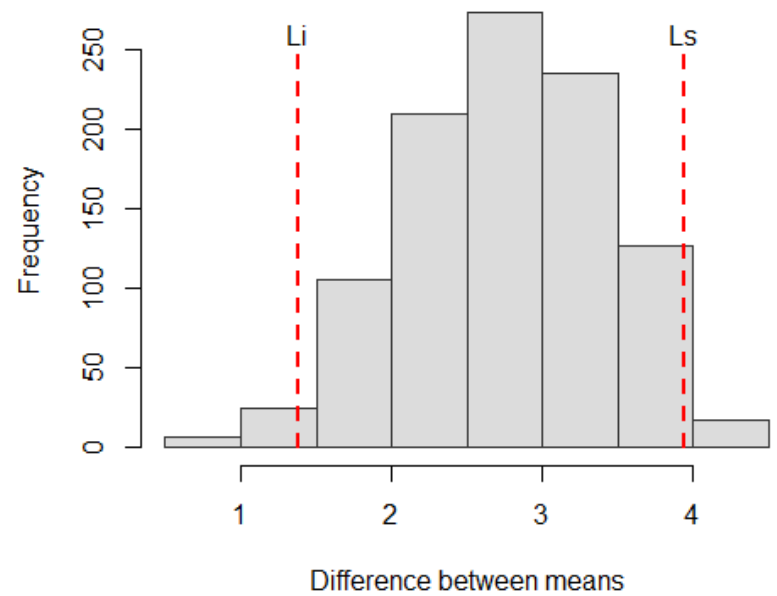

Figure 4: Histogram of the empirical distribution of the difference between the means of the ultimate shear stress of CC and SCC

Evaluating the $95 \%$ confidence interval highlighted in Figure $4(1.39 ; 3,90)$, it is verified that the means are different because the value zero, which would represent the equality between the means, is not in the interval. This demonstrates that the reduction of coarse aggregate content to produce the SCC influenced the shear strength, confirming the results presented at literature [10,11].

Considering that the shear strength in unreinforced concrete is formed only by the aggregate interlock and the adhesive bonding of the particles of the materials [9], it was decided to normalize the shear loads, to consider the variation in concrete compressive strength, using Equation 5, and results are presented in Table 4.

$$
\tau_{\mathrm{un}}=\frac{\tau_{\mathrm{u}}}{\sqrt{f_{c m}}}
$$

where $\tau_{\text {un }}$ is the normalized ultimate shear stress $\left(\mathrm{MPa}^{0,5}\right), \tau_{\mathrm{u}}$ is the ultimate shear stress (MPa) and $\mathrm{f}_{\mathrm{cm}}$ is the concrete mean compressive strength $(\mathrm{MPa})$.

Table 4: Normalized ultimate shear strength of CC and SCC specimens.

\begin{tabular}{c|c|c}
\hline \multirow{2}{*}{ SPECIMEN } & \multicolumn{2}{|c}{$\mathbf{T}_{\mathrm{u}, \mathbf{n}}\left(\mathbf{M P a}^{0,5}\right)$} \\
\cline { 2 - 3 } & $\mathbf{C C}$ & $\mathbf{S C C}$ \\
\hline 1 & - & 0.61 \\
\hline 2 & - & 0.62 \\
\hline 3 & 1.09 & 0.48 \\
\hline 4 & 1.25 & 0.57 \\
\hline 5 & 0.72 & 0.58 \\
\hline 6 & 1.05 & 0.50 \\
\hline Mean stress (MPa) & 1.03 & 0.56 \\
\hline Standard deviation (MPa) & 0.22 & 0.06 \\
\hline
\end{tabular}

Using the same statistical analysis beforehand presented, the 95\% confidence interval highlighted in Figure $5(0.26 ; 0.64)$ it is verified that the ultimate shear strengths of the CC and SCC mixtures are different, since the zero value for the differences between the means is not in the range. CC presented normalized ultimate shear strength $45.5 \%$ higher than SCC, demonstrating that changes in the mixture to produce SCC influenced the shear strength. As demonstrated by SHERWOOD et al. [14] and SAVARIS et al. [11] the reduction of coarse aggregate nominal size influences the mechanisms of aggregate interlock and the roughness of the crack interface, reducing the shear strength. In addition, the improvement of concrete matrix resulting in higher shear strength in SCC, as proposed by DESNERCK et al. [12], was not observed in concrete specimens without reinforcement. 


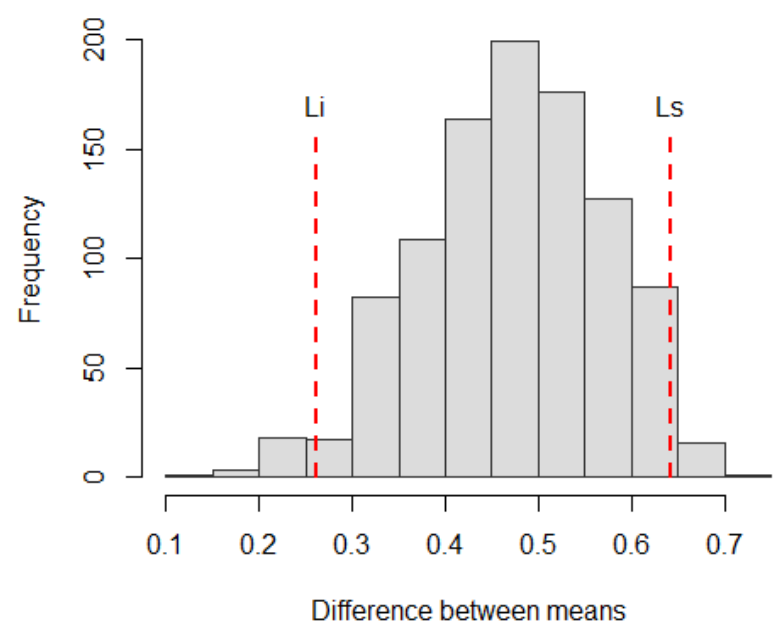

Figure 5: Histogram of the empirical distribution of the difference between the means of the normalized ultimate shear stress of CC and SCC

\subsection{Comparison of experimental and theoretical shear resistance}

The experimental results obtained in this work were compared with the values calculated using the equations proposed by MATTOCK [16], SONNENBERG et al. [17] and XU et al. [18], and results are presented in Table 5.

Table 5: Experimental shear strength of CC and SCC and theoretical estimates.

\begin{tabular}{c|c|c|c|c|c|c|c}
\hline \multirow{2}{*}{ MIXTURE } & \multirow{2}{*}{$\begin{array}{c}\text { Experimental ultimate shear stress } \\
\text { (MPa) }\end{array}$} & \multicolumn{2}{|c|}{ Theoretical ultimate shear stress (MPa) } & \multicolumn{3}{|c}{$\tau_{\text {theo }} / \tau_{\exp }$} \\
\cline { 3 - 8 } & & {$[16]$} & {$[17]$} & {$[18]$} & {$[16]$} & {$[17]$} & {$[18]$} \\
\hline CC & 6.97 & 3.77 & 4.62 & 5.32 & 0.54 & 0.66 & 0.76 \\
\hline SCC & 4.19 & 4.22 & 5.63 & 6.16 & 1.01 & 1.34 & 1.47 \\
\hline
\end{tabular}

Conventional concrete theoretical ultimate shear strengths were lower than the values obtained experimentally, ensuring safety of the structures. XU et al. [18] presented result closest to experimental value because this equation was based on extensive non-linear numerical analysis, while the other equations were based on a few experimental test results. The differences between theorical and experimental may also result from the type of specimens used, since equations were based on push-off tests with and without reinforcement, and in this work only direct shear test with non-reinforced prismatic specimens were carried out.

The results estimated for SCC were higher than mean value obtained in this experiment. This result is due to the equations were defined from experimental studies with $\mathrm{CC}$. These results demonstrated lower safety for concrete structures cast with SCC and justify that further research must be carried out to adjust the existing equations presented at design codes to the use of SCC.

\section{CONCLUSIONS}

The results obtained with this work demonstrated that is possible to obtain a mixture of SCC from CC with the partial replacement of sand by limestone filler and the reduction of the coarse aggregate content, resulting a SCC with higher compressive and tensile strength.

Although the addition of fines has resulted in improvements in the concrete matrix, it was found that for concrete specimens without reinforcement, the shear strength attributed to aggregates interlock corresponds to a portion greater than the adhesion between particles, and reduction in coarse aggregate content resulted in lower shear strength in SCC when compared to CC.

The equations presented by MATTOCK [16], SONNENBERG et al. [17] and XU et al. [18] for estimating the shear strength of the concrete were adequate for conventional concrete, however, they require adjustment for use with SCC, because it presents higher values than those obtained experimentally.

\section{ACKNOWLEDGEMENTS}

The authors would like to thank the Federal University of Technology - Paraná, campus Toledo and the Ma- 
terials and Structures Research Group (GPMAES) for their support for this research.

\section{REFERENCES}

[1] OKAMURA, H., OUCHI, M., "Self-Compacting Concrete", Journal of Advanced Concrete Technology, v. 1 , n. 1 , pp. $5-15,2003$.

[2] LOONEY, T.J., AREZOUMANDI, M., VOLZ, J.S., et al., "An Experimental Study on Bond Strength of Reinforcing Steel in Self-Consolidating Concrete", International Journal of Concrete Structures and Materials, v. 6, n. 3, pp. 187-197, 2012.

[3] GOMES, P.C.C., GETTU, R., AGULLÓ, L., "El hormigón Autocompactable. Propriedades y métodos de caracterización", Hormigón y Acero, v. 221, p. 5-16, 2003.

[4] MELO, C.V.A., GOMES, P.C.C., MORAES, K.A.M., "A study of packing parameters that influence the fresh properties of self-compacting concrete", Cerâmica, v. 65, p. 432-442, 2019.

[5] SCHANKOSKI, R.A., PILAR, R., PILEGGI, R., et al. "Rheology evaluation of self-compacting concretes containing quarry by-product powders", Revista Matéria, v. 22, n. 2, 2017.

[6] MENDES, M., BAUER, E., SILVA, F. "Evaluation of the workability and rheology parameters of selfcompacting concrete", Revista Matéria, v. 22, n. 4, 2017.

[7] BARBOZA, L.S., ALMEIDA FILHO, F.M., "Self-compacting concrete with low cement consumption: impact of the reduction of cement consumption on the compressive strength", Revista Matéria, v. 23, n. 3, 2018.

[8] SHARIFI, Y., "Structural Performance of Self-consolidating Concrete Used in Reinforced Concrete Beams", KSCE Journal of Civil Engineering, v. 16, n. 4, pp. 618-626, 2012.

[9] HASSAN, A.A.A., HOSSAIN, K.M.A., LACHEMI, M., "Behavior of full-scale self- consolidating concrete beams in shear." Cement and Concrete Composites, v. 30, n. 7, pp. 588-596, 2008.

[10] HELINCKS, P., BOEL, V., CORTE, W., et al. "Structural behavior of power-type self-compacting concrete: Bond performance and shear capacity", Engineering Structures, v. 48, pp. 121-132, 2013.

[11] SAVARIS, G., PINTO, R.C.A., "Influence of coarse aggregate on shear resistance of self-consolidating concrete beams", Ibracon Structures and Materials Journal, v. 10, n. 1, pp.30-52, 2017.

[12] DESNERCK. P., SCHUTTER, G., TAERWE, L., "Shear friction of reinforced self-compacting concrete members", In.: American Concrete Institute Special publication 261-9, pp. 133-141, Farmington Hills, MI, 2009.

[13] RANDL, N., "Design recommendations for interface shear transfer in fib Model Code 2010", Structural Concrete, v. 14, n. 3, pp. 230-241, 2013.

[14] SHERWOOD, E.G., BENTZ, E.C., COLLINS, M.P., "Evaluation of shear design methods for large, lightly-reinforced concrete beams". In.: International Conference on Advances in Engineering Structures, Mechanics \& Construction, Springer, p. 153-164, Netherlands, 2006.

[15] KIM, Y.H., HUESTE, M.B.D., TREJO, D., et al. "Shear Characteristics and Design for High-Strength Self-Consolidating Concrete", Journal of Structural Engineering, v. 136, n. 8, pp. 989-1000, 2010.

[16] MATTOCK, A.H. "Reader comments of: Influence of concrete strength and load history on the shear friction capacity of concrete member", PCI Journal, v. 33, n.1, pp. 165-170, 1988.

[17] SONNENBERG, A.M.C., AL-MAHAIDI, R., TAPLIN, G., "Behaviour of concrete under shear and normal stresses", Magazine of Concrete Research, v. 55, p. 4, pp. 367-372, 2003.

[18] XU, J., WU, C., LI, Z. C., et al. "Numerical analysis of shear transfer across an initially uncrack reinforced concrete member", Engineering Structures, v.102, pp. 296-309, 2015.

[19] JAPAN SOCIETY OF CIVIL ENGINEERS - JSCE, SF6: Method of test for shear strength of steel fiber reinforced concrete, Tokyo, 1990.

[20] BRAZILIAN ASSOCIATION OF TECHNICAL STANDARDS - ABNT, NBR NM 67: Concrete -

Slump test for determination of the consistency, Rio de Janeiro, 1998.

[21]___ NBR 15823: Self-consolidating concrete, Rio de Janeiro, 2010.

[22] ___ NBR 5739: Concrete - Compression test of cylindrical specimens, Rio de Janeiro, 2007.

[23] ___ NBR 7222: Concrete and mortar - Determination of the tension strength by diametrical compression of cylindrical test specimens, Rio de Janeiro, 2011.

[24] ___ NBR 8953: Concrete for structural use - Density, strength and consistence classification, Rio de Janeiro, 2015.

[25] EFNARC, The European Guidelines for Self-Compacting Concrete, Eur. Guidel. Self Compact. Concr. UK, 2005.

[26] SAVARIS, G. Shear resistance of self-consolidating concrete, Doctoral Thesis (in Portuguese), Federal University of Santa Catarina, Florianópolis, Brazil, 2016. 
[27] DOMONE, P.L., "Self-compacting concrete: An analysis of 11 years of case studies", Cement \& Concrete Composites, v. 28, pp. 197-208, 2006.

[28] EFRON, B., TIBISHIRANI, R.J., An introduction to the bootstrap, New York, John Wiley \& Sons, 1993.

[29] R DEVELOPMENT CORE TEAM. $R$ : A language and environment for statistical computing. R Foundation for Statistical Computing, Vienna, Austria, 2018.

\section{ORCID}

Kellyn Maressa Pufal

https://orcid.org/0000-0001-6861-8614

Gustavo Savaris

https://orcid.org/0000-0002-3311-2426

Carlos Eduardo Tino Balestra

https://orcid.org/0000-0001-7624-7921

Gustavo Henrique Dalposso

https://orcid.org/0000-0003-2097-5748

Sergio Luis González Garcia

https://orcid.org/0000-0002-3265-6771 